\title{
ASSESSING THE QUALITY OF GASTRONOMY EDUCATION: TURKEY CASE*
}

\author{
GASTRONOMİ EĞİTIM KALITTESININ DEĞERLEDIRILMESI: TÜRKIYE \\ ÖRNEĞİ
}

\section{Duran CANKÜL ${ }^{1}$}

\begin{abstract}
Gastronomy education in Turkey is given under the names of "food and beverage management" and "gastronomy and culinary arts" in degree programs and "culinary" in associate degree programs. In these sections where students are active in a significant part of the educational process, the physical facilities, curriculum, lecturer, student and database dimensions are important in determining the quality of education. In this research, it is aimed to evaluate the quality of gastronomy education at the higher education level in Turkey. In this direction, the questionnaire method was used for data collection. These questionnaires were sent all gastronomy lecturers and the students including private universities in Turkey. 400 students and 102 academics a total of 502 questionnaires have returned and taken into consideration. The obtained data were analyzed with SPSS packet program. Analised results present very interesting findings about the quality of gastronomy education at higher education level in Turkey. It is seen that the physical facilities, databases and curriculum offered during the education in these sections do not satisfy both the academicians and the students and are not sufficient. In addition, quality of gastronomy education scores show meaningful and significant differences according to the type of university trained and the degree of education.
\end{abstract}

Keywords: Culinary, Food and Beverage Management, Gastronomy, Gastronomy Education, Quality.

\section{$\ddot{O} z$}

Türkiye'de gastronomi eğitimi yiyecek içecek işletmeciliği ve gastronomi ve mutfak sanatları adları altında lisans programlarında aşçılık adı altında da ön lisans programlarında verilmektedir. Öğrencilerin eğitim süreçlerinin önemli bir kısmında aktif olduğu bu bölümlerde, eğitimin kalitesinin belirlenmesinde etkili olan fiziksel imkanlar, müfredat, eğitimci, öğrenci ve veri tabanları boyutları önemli bir yer tutmaktadır. Bu araştırmada Türkiye'de yükseköğretim düzeyinde verilen gastronomi eğitim kalitesinin değerlendirilmesi amaçlanmaktadır. Bu doğrultuda araştırmada veri toplama yöntemi olarak anket tekniğinden yararlanılmış olup, Türkiye'deki vakıf üniversiteleri de dahil tüm üniversitelerin ön lisans ve lisans düzeyinde gastronomi ile ilgili eğitim veren kurumlarda görevli akademisyenlere ve eğitim alan öğrencilere uygulanmış ve 400'ü öğrenci 102'si akademisyen olmak üzere toplam 502 anket değerlendirilmeye alınmıştır. Elde edilen veriler SPSS paket programı ile analiz edilmiştir. Analiz sonuçları Türkiye'de yükseköğretim düzeyinde verilen gastronomi eğitim kalitesi hakkında çok dikkat çekici sonuçlar ortaya koymaktadır. Bu bölümlerde eğitim süresince sunulan fiziksel imkânların, veri tabanlarının ve uygulanan müfredatın hem akademisyenleri hem de öğrencileri tatmin etmediği ve yeterli olmadığı görülmektedir. Ayrıca gastronomi eğitimi, eğitim alınan üniversitenin türüne (devlet veya vakıf), eğitimin süresine (önlisans veya lisans) ve eğitim alınan bölüme (aşçılık veya gastronomi) göre anlamlı ve önemli bir farklılık göstermektedir.

Anahtar Kelimeler: Aşçılık, Yiyecek İçecek İşletmeciliği, Gastronomi, Gastronomi Eğitimi, Kalite.

* This article has been presented in 11th Tourism Outlook Conference as an abstract

${ }^{1}$ Dr.Öğr.Üyesi, Eskişehir Osmangazi Üniversitesi, dcankul@ ogu.edu.tr, Orcid: 0000-0001-5067-6904

Makale Türü: Araştırma Makalesi - Geliş Tarihi:01-12-2018 - Kabul Tarihi:20-03-2019

DOI:10.17755/esosder.491083 


\section{INTRODUCTION}

As supporting role of higher education, research and innovation in achieving social cohesion, economic growth and global competitive advantage is critical (ESG, 2015). Education is at the source of all personal, social and national improvements. Strategies put forward with quality awareness and scientificness in every aspect of education can be regarded as the most profitable future investment as they are both long term and versatile. Faculty, physical facilities, student, curriculum and database dimensions that are effective in determining the quality of education. They have an important place in institutions that provide gastronomy and culinary education, where the size of the application is intensive and the students are active as a significant part of the education process. This study aims to evaluate the quality of gastronomy education at the national level in Turkey.

Whether bachelor' or associate's degree in Turkey, it is clear that it had been too late in the gastronomy education, but despite the number of lecturers of today's program, lack of kitchen equipment and material supply also shows that have been in rush so far (Görkem and Sevim, 2016). In addition, almost half of students in the field of culinary education in Turkey have developed negative attitudes in enthusiasm for the profession (Kurnaz, Kurnaz and Kılıç, 2014). This research is important to set standards that will enable the evaluation of the success and quality levels of institutions that provide gastronomy and culinary education. It is imperative for students to have qualified education in order not only to keep up with the industry and also to lead it. The first condition of reaching the target is to walk on the right path. With the standards set forth in this study, a right path is proposed for education, which is the first step towards the culinary profession.

\section{LITERATURE}

\section{Gastronomy Education}

The roots of today's cooking education is based on the teaching methods (learning by doing) of the time that former Swiss, American, French, and Austrian chiefs conducted for commis education. Today's culinary education is carried out by educated chefs in high school and college-level schools, enabling students to transform raw material into aesthetic plates by developing their innovation, intuition, intelligence, imagination and sensory technical abilities in the direction of their talents (Brown, 2013). Today's chefs are required to have knowledge of food science, food technology, food consumption and practices at an expert level in gastronomy, and professional skills that industry needs. In addition to these, analytical and critical thinking are other qualities sought. The development of the curriculum and its educators in line with these needs will benefit the sector and graduates (Zahari, Jalis, Zulfifly, Radzi and Othman, 2009). Culinary art education should involve students' commitment in imagination at cultural, artistic, political level rather than repeating the same contents of school curricula. Education system planned on this base will bring about the transformative effect of education for both students and educators (Hegarty, 2011). Gastronomy and especially gastronomy education is now being addressed with philosophical, artistic, practical and interdisciplinary dimensions and kinds of approaches to the field are being developed. FAMM (Five Aspects Meal Model) and DiciplineBased Art Education are some of them.

The FAMM (Five Aspects Meal Model) offers an educational model that includes philosophy, practice, and interdisciplinary approaches. In the philosophical dimension; The 
question of "who, how, when, why, what and where" about eating is tried to understand from psychology to sociology, from personal experience to complex product. Its wievpoints are management, health concerns and the person. Interdisciplinary formation contributes to the multi-value of the product by avoiding it as a single point of view and understanding (Gustafsson, Öström and Annett, 2009). Theoretical and practical training plans in gastronomy education should be fictionalised in this framework, taking into consideration a wide field, scope and function of gastronomy. In gastronomy education, the acquisition of art, philosophy and artistic point of view is as important as giving hands-on skills training.

The theory of Dicipline-Based Art Education consists of four components. 1) production performing art, 2) criticism - judgment, perception and explanation the art, 3) art history - art when and where the culture entered, and 4) aesthetics - quality of art. DTSE is not a curriculum, it offers a wide range of options for the best approach for the teachers facing problems. It enables teachers to obtain critical answers from students rather than developing customary approaches to the problems (Brown, 2014). The greatest contribution of this method to students is to gain critical thinking ability. Just as in other educational areas, the goal of educating students who are thinking, questioning, and carrying the knowledge forward is in the center of gastronomy education. In line with this goal, the nature, location, shape and sides of gastronomy education should be considered in planning, operating. The effectiveness of education is provided and should be updated with continuity of feedback.

Brown, Mao and Chesser pointed out the interpersonal interaction in live training, and the positive effect of teamwork on team spirit and creativity. They say some methods like peer teaching, virtual meetings, appropriate discussion boards, blogsharing, social media communication, etc., could be used in gastronomy and culinary education (Brown, Mao and Chesser, 2013). Way, Ottenbacher and Harrington have mentioned "crowdsourcing" method and argued that using social networks as online communication and interaction tool will be the best solution for questions and problems by providing multiple participation (Way, Ottenbacher and Harrington, 2011). Drawing attention to teamwork and interpersonal interaction, Hegarty emphasized the importance of critical thinking in developing students' cultural imagination and creativity (Hegarty, 2011). Müller and Harrington are also among those who relate communication skills to sectoral success (Müller and Harrington, 2009). According to Ko, it is important to acquire professional skills in gastronomy education. Also, argued the necessity of professional chefs, seminars and courses for both in increasing the output of the education and in the career development of the students by acquiring professional abilities (Ko, 2012). Zopiatis, Theodosiou, and Constanti argue that the initiative and cooperation that will shorten the distance between the sector and educational institutions; instructors can be developed with practices such as on-the-job training, national and international competitions, research projects, industry consultancy, seminar-style courses, advice panels (Zopiatis, Theodosiou and Constanti, 2014). About another important title of education, Wollin and Gravas have pointed out that there is no common practice in curriculum content (Wollin and Gravas, 2013). Ko mentions that educators should build curricula verbally, with feedback they receive (Ko, 2012). Öney argued that the curriculum should be structured interdisciplinarity in the context of art, culture, cooking, foodnutrition, and it is important to apply the views of sector professionals in the application course content (Öney, 2016). According to Santich, while educating in gastronomy, educators should equip the students with the ability to fulfill their duties and responsibilities, rather than conveying general information to them only with the curriculum (Santich, 2004). The curriculum in gastronomy and culinary education is like a menu of a restaurant. It reflects its target market, 
production strategy, marketing activities, physical structure, personnel quality and quantity, etc. A map on the way out. So, about gastronomy and culinary education at national level, to look at the curriculum will give clues in order to anticipate the future.

When international publications on gastronomy education (Hertzman and Ackerman, 2010) (Naidu and Derani, 2016) (Ko, 2012) (Wollin and Gravas, 2013) (Ko and Chiu, 2011) (Kuo, Burnard, McLellan, Cheng and $\mathrm{Wu}$, 2017) (Abdullah, 2006) and educational quality acreditations (ACF, 2018) (Ontario, 2018) (GACHEF, 2018) (WACS, 2018) are examined, it is seen that qualifications are generally covered under the dimensions of curriculum, faculty, student, physical facilities, database.

The curriculum expresses the mission, goals and objectives of an educational institution (ACF, 2018). Curricula is one of the most important quality indicators in education which students can take an active role in learning processes, open to flexible learning, meet student needs / expectations, shaped by feedback from students, and compatible with international acreditations (ESG, 2015). Research shows that there is no curriculum content standard among educational institutions. Moreover, there are disagreements about the inclusion of health and art disciplines and their weighting (Wollin and Gravas, 2013). When the curriculum of gastronomy and culinary education is examined; there is an agreement on curriculum include art, culture, cooking, food and nutrition in a multidisciplinary way (Öney, 2016) (Santich, 2004). However, this opinion, which is also dominant among Turkish academicians, is not reflected in the present curricula. This difference between the discourses and practices of institution managers and academicians in gastronomy and culinary education requires a scientific research.

Student-centered learning, teaching and assessment is one of the basic principles of quality in higher education (ESG, 2015). In student-centered researches these are the approaches developed; effective learning (Ko, 2012), team work and organizational behavior (Way, Ottenbacher and Harrington, 2011), communication abilities (Müller and Harrington, 2009), critical point of view (Hegarty, 2011), live ve online courses (Brown, Mao and Chesser, 2013), technological knowledge (Zahari, Jalis, Zulfifly, Radzi and Othman, 2009), food ethics (Shani, Belhassen and Soskolne, 2013), philosophy (Gustafsson, Öström and Annett, 2009), innovation, intuition, intelligence, imagination and sensory technique (Brown, 2013). Suggestions have been developed to enable students to acquire the skills they will need for both their educational and professional lives. Kozak and Açıköz have put forth a different perspective about enrollment sufficiencies of students' qualifications by expressing its importance in terms of the quality of the educational output (Kozak and Açıköz, 2015). Öney has stated that the problems as to the internship and workplace training for the sectoral integration of students should be solved (Öney, 2016).

The competence of the faculty, who is another aspect of gastronomy education quality, is under the responsibility of the institutions. Institutions should behave transparently and fairly during the recruitment and development of faculty (ESG, 2015). Teaching staff employment policies should be defined and written (ACF, 2018). Faculty is also an important indicator of the quality perception of education institutions. Efforts on sociability and cooperation to shorten the distance between the sector and educational institutions; they can be developed via applications such as on-the-job training, national and international competitions, research projects, industry consultancy, seminar style courses, advice panels (Zopiatis, Theodosiou and Constanti, 2014). Faculties are expected to equip themselves with the ability to fulfill their duties and responsibilities, rather than merely giving general information from curriculum to the students 
(Santich, 2004). Incorporate some teaching staff from other departments and different disciplines, and ensuring that the industry professionals participate in courses can be a solution to the problems originating from teaching staff.

When gastronomy education staff in Turkey is analyzed, the proportion of whose education field is related is seen as only 5.4\% (Temizkan, Cankül and Kızıltaş, 2018). This rate is the result of restrictions on developing and finding the instructors who will provide gastronomy education quality in Turkey. In gastronomy training the qualifications of faculty, their education, scientific and philosophical levels should be examined. Lecturers should also play a role in targetting lifelong learning while transferring theory to practice (Öney, 2016). It is important in terms of quality of education that the requirements for faculty should be revalled quantitatively and qualitatively when planning gastronomy education nationally, and the recruitments have to be carried out transparently and fairly through these standards.

It is a requirement of educational quality that institutions have adequate and accessible resources for learning and teaching (ESG, 2015). In institutions offering gastronomy education, building a laboratory environment donated with necessary / adequate equipment, and having an available financial power to procure goods for courses are the fundamentals of giving professional competencies. Having not an adequate funding sources, policies on reducing the application courses and processing these courses theoretically, etc. are far from the quality and responsibility of education.

Educational institutions should publish teaching and learning supportive activities, programs, resources and related links with accessible, impartial, accurate information, and timely (ESG, 2015). Accesible and intelligible interface of website is important for students to reach written and visual informations and linkages like accreditation bodies, professional organizations, competitions, certifications, etc. (Zopiatis, Theodosiou and Constanti, 2014).

To improve the quality of gastronomy education in Turkey, primarily, it is necessary to analyse the present situation and create quality standards nationally. The first step to be in and to increase the gainings of the food and tourism sectors is education. Mistakes to be made in the first step will cause large deviation in the long run.

\section{Gastronomy Education in Turkey}

Gastronomy education in Turkey are given under the name of "culinary" in associate degree programs, and "gastronomy and culinary arts" and "food and beverage management" in degree programs. There are 184 universities giving gastronomy education in Turkey (112 state, 67 foundations and 5 private vocational colleges) (YÖK, 2017). Detailed information is given below about undergraduate programs in these universities.

\section{Culinary in Associate Degree Programs}

According to the Higher Education Council (YÖK) 2016 results; there are 168 (62 state, 94 foundation) associate degree programs in Turkey. Of the programs in state universities, 40 are "daytime education", 21 are "evening education" and 1 is "open education". Four new programs were opened already. All of the 58 public university programs in the open status have filled their quotas. In the foundation universities, 58 programs were filled in quotas, 12 could not be filled and 24 new programs were opened (YÖK, 2016). 


\section{Degree Programs}

This graduation is given in two programs; "gastronomy and culinary arts" and "food and beverage management". There are 67 (23 states and 44 foundations) "Gastronomy and Culinary Arts" in Turkey. 5 of these programs are "Evening Education (EE)" and are in state universities. While 51 of all programs have filled quotas, 7 coulnd't have been filled and 9 have never received any students. All programs that have not filled their quota are foundation universities. All programs accept students with verbal score types. 22 of the programs in the state universities are in the "Faculty of Tourism" and 1 in the "Faculty of Fine Arts". Of the 44 programs in the foundation universities, 8 are in the "Tourism Faculty", 21 are in the Faculty of Fine Arts, 12 are in the Faculty of Art and Design, and 3 are in the Faculty of Applied Sciences (YÖK, 2016).

There are 7 Food and Beverage Management programs in Turkey. 3 of these programs are "Evening Education (EE)" and they are all in state universities. Of these programs, 4 are in the "Tourism Faculty" and 3 are in the "Tourism Management and Hotel Management School". All these numbers help us to understand the popularity of gastronomy education institutions in Turkey.

\section{METHODOLOGY}

This research aims to evaluate the quality of gastronomy education at the tertiary level in Turkey. For this purpose, the survey technique was used to have evaluations about the quality of gastronomy education both from academicians and students in the field of gastronomy. The questionnaire was composed of five factors: physical facilities / campus, curriculum, database, faculty and student. There are 57 items in these five factors. The items are gathered from academic literature (Abdullah, 2006, Hertzman and Ackerman, 2010, Ko and Chiu, 2011, Ko, 2012, Wollin and Gravas, 2013, , Naidu and Derani, 2016 Kuo, Burnard, McLellan, Cheng, f $\mathrm{Wu}, 2017$ ), and acreditation programs (ACF, 2018, Ontario, 2018, GACHEF, 2018, WACS, 2018). The questionnaire also includes questions to determine the demographic characteristics. Data was collected through online questionnaires sent academicians and their students studying in gastronomy and culinary programs in Turkey. In this process, one academicians from departments and programs was reached through social media and telephone, and he/she was asked to send the questionnaire to other lecturers and students. At the end of the data collection process, the number of the questionnaires obtained from the academicians in the online questionnaire form was 102 and the number of the questionnaires obtained from the students was 400.

Research universe is all academicians and the students from gastronomy and culinary programs in Turkey. Convenience sampling method was used for determining the sample groups. The universe of gastronomy academicians is all academicians lecture in gastronomy programs in 2017-2018, in state and foundation üniversities, in Turkey. In these programs, there are 369 academicians (Temizkan, Cankül and Kızıltaş, 2018). Considering the universe (N: 369), sampling number (102) is enough to represent it (Ural and K1liç, 2006: 49). The universe of gastronomy students is all students study in gastronomy programs in 2017-2018, in state and foundation üniversities, in Turkey. Sampling number (400) is enough to represent the universe under 10.000 (Ural and Kılıç, 2006, pp. 49). 
In the analysis of the data, the SPSS program was used. Data related to control variables and expressions were evaluated using frequency, percentage, arithmetic mean and standard deviation values and the results were tabulated and interpreted. In order to determine whether there is a significant difference in terms of control variables, independent sample $t$ test and variance analysis (anova) were used.

\section{FINDINGS}

\section{Findings Regards to Academicians}

\section{Demographic Characteristics of Academicians}

Demographic characteristics of the academicians of gastronomy and culinary departments are given in Table 1 . When Table 1 is examined, it is seen that $84.3 \%$ of the academicians work at the state university and $15.7 \%$ work at the foundation university. $70.6 \%$ of the academicians work in the culinary programs and $29.4 \%$ work in the department of gastronomy and culinary arts.

\begin{tabular}{clrr}
\hline \multicolumn{2}{l}{ Table 1: Demographic Characteristics of Academicians (n: 102) } & \\
\hline \multirow{2}{*}{ Universty } & & $\mathbf{n}$ & \% \\
\hline \multirow{2}{*}{ Department } & State & 86 & 84,3 \\
\cline { 2 - 5 } & Foundation & 209 & 15,7 \\
\hline & Gastronomy and culinary departments & 30 & 29,4 \\
\cline { 2 - 5 } & Culinary & 162 & 70,6 \\
\hline
\end{tabular}

\section{Arithmetic Mean and Standard Deviation of Academicians as to Evaluating Gastronomy Education Quality}

The academicians were asked to indicate a value from 1 to 5 according to a 5-point Likert scale to assess the quality of the gastronomy education. The arithmetic mean $\mathrm{x}^{-}$and standard deviation (s.s) values related to evaluation of gastronomy education quality are shown in Table 2 .

Table 2: Arithmetic Mean and Standard Deviation of Academicians as to Evaluating Gastronomy Education Quality

\begin{tabular}{|c|c|c|c|c|}
\hline Factors & Statements & $\overline{\mathrm{x}}$ & s.s. & $\begin{array}{l}\text { Factors } \\
\text { Means }\end{array}$ \\
\hline \multirow{7}{*}{ Curriculum } & $\begin{array}{l}\text { Theoretical courses of the curriculum includes different disciplines } \\
\text { (communication, agriculture, sociology, chemistry, art and accounting) }\end{array}$ & 2,72 & 1,379 & \multirow{7}{*}{2,74} \\
\hline & $\begin{array}{l}\text { The curriculum includes courses which improves creativity and } \\
\text { imagination }\end{array}$ & 2,69 & 1,405 & \\
\hline & Course lecturers are experts of their fields & 2,69 & 1,280 & \\
\hline & Applied courses are of enough variety & 2,43 & 1,293 & \\
\hline & Applied courses are of enough number & 2,55 & 1,473 & \\
\hline & Applied courses are of enough hours & 2,52 & 1,571 & \\
\hline & There are repetitive courses in the curriculum & 3,40 & 1,443 & \\
\hline
\end{tabular}




\begin{tabular}{|c|c|c|c|c|}
\hline & $\begin{array}{l}\text { The curriculum is prepared according to needs and expectations of the } \\
\text { industry }\end{array}$ & 2,61 & 1,379 & \\
\hline & Course contents support team working & 3,06 & 1,351 & \\
\hline \multirow{5}{*}{ Data base } & Webpage of the school presents e-sources for vocational training & 2,24 & 1,293 & \multirow{5}{*}{2,37} \\
\hline & $\begin{array}{l}\text { Webpage of the school includes information for pursuit of vocational } \\
\text { trends }\end{array}$ & 2,20 & 1,322 & \\
\hline & Webpage of the school has links for information outsources & 2,29 & 1,309 & \\
\hline & $\begin{array}{l}\text { Webpage of the school presents information on vocational activities such } \\
\text { as culinary contents, conferences, seminaries and fairs }\end{array}$ & 2,58 & 1,146 & \\
\hline & $\begin{array}{l}\text { Webpage of the school has a user friendly (easy to access and use) } \\
\text { interface }\end{array}$ & 2,51 & 1,318 & \\
\hline \multirow{13}{*}{$\begin{array}{l}\text { Physical } \\
\text { facilities }\end{array}$} & There enough computers and usage opportunties & 2,50 & 1,347 & \multirow{13}{*}{2,74} \\
\hline & There are enough electronic and printed sources in the library & 2,42 & 1,352 & \\
\hline & There are enough sectoral practice facilities out of the school & 2,80 & 1,312 & \\
\hline & There enough accomodation facilities for the students & 2,74 & 1,419 & \\
\hline & There enough funding sources for the students & 2,38 & 1,259 & \\
\hline & $\begin{array}{l}\text { There are enough technological training equipment (projector, sound } \\
\text { system etc.) in the classrooms }\end{array}$ & 3,31 & 1,319 & \\
\hline & There are enough practice facilites in the school & 2,85 & 1,337 & \\
\hline & $\begin{array}{l}\text { There are enough application kitchen equipment for preparing students } \\
\text { for the sector }\end{array}$ & 2,84 & 1,303 & \\
\hline & The applicaiton kitchen is sanitized and hygenic enough & 3,22 & 1,319 & \\
\hline & The lecturers-students ratio in applicational courses is appropriate & 2,27 & 1,387 & \\
\hline & There is no stock provision problems in the application kitchen & 2,41 & 1,498 & \\
\hline & The campus is secure enough & 3,53 & 1,271 & \\
\hline & $\begin{array}{l}\text { The campus has enough social facilites such as café, cinema, restaurant } \\
\text { etc. }\end{array}$ & 2,34 & 1,331 & \\
\hline
\end{tabular}

\section{Continued from Table 2}

\begin{tabular}{lllll}
\hline \multirow{2}{*}{ Factors } & \multicolumn{1}{c}{ Statements } & $\overline{\mathrm{x}}$ & s.s. & $\begin{array}{c}\text { Factors } \\
\text { Means }\end{array}$ \\
\hline \multirow{3}{*}{ Student } & \multicolumn{1}{c}{ Attends the lectures regularly } & 3,88 & 0,947 \\
\cline { 2 - 4 } & Shows enthusiasm for teamwork and cooperation & 3,81 & 0,982 \\
\cline { 2 - 4 } & $\begin{array}{l}\text { Has enough capacity of understanding the duties given and learning the } \\
\text { theoretical knowledge }\end{array}$ & 3,68 & 0,994 & $\mathbf{3 , 5 8}$ \\
\cline { 2 - 4 } & Uses initiatives (takes responsibility) & 3,72 & 0,986 \\
\cline { 2 - 4 } & Is enthusiastic about vocational improvement & 3,99 & 0,838 \\
\cline { 2 - 4 } & Has problem solving skills & 3,70 & 0,929 \\
\hline
\end{tabular}




\begin{tabular}{lcc} 
Appreciates other students' performances & 3,30 & 1,022 \\
\hline Is sociable during the practices and operations & 3,60 & 1,063 \\
\hline Is respectful to different thoughts and point of views & 3,50 & 1,105 \\
\hline Is confident and enthusiastic for sharing own opinions & 3,56 & 0,938 \\
\hline Reveals her/his personality to the plate in application courses & 3,62 & 0,974 \\
\hline Questions the provided knowledge and duties in the classes & 3,26 & 1,089 \\
\hline Has memberships of vocational unions and communities & 2,84 & 1,391 \\
\hline Follows the latest vocational trends & 3,36 & 1,115 \\
\hline Aims further education & 3,84 & 1,149
\end{tabular}

As seen in Table 2, academicians had a low agreement on curriculum $(2,74)$, database $(2,37)$ and physical facilities factor $(2,74)$ while high agreement on student factor $(3,58)$. When the means of the evaluations about the gastronomy education quality of the academicians are examined individually and the means of the factors are taken into account. It is seen that they generally express negative comments in the other factors besides the student factor. In particular, "The diversity of application courses is sufficient" $(2,43)$, "The number of vocational field resources in the library is sufficient." $(2,42)$, "There are links on the web page that provide access to different information sources" $(2,20)$, "The school web site offers resources that support vocational education (e-learning)." $(2,24)$, "The ratio of teaching staff - students in practical courses is suitable. "(2,27)," Campus has social facilities (cafes, cinemas, restaurants, etc.) "(2,34) and" Students can find sufficient financial support " $(2,38) "(2,41)$ were significantly lower than the average of 2,50. In these statements, academicians consider the quality of gastronomy education very low.

\section{Findings Related to Independent Sample t Test Analysis}

An independent sample t-test was applied to determine whether there is a significant difference in curriculum, database, physical facilities and student factors according to the university (state, foundation) of academicians. As shown in Table 3, a statistically significant difference was found between the academicians' universities and curriculum, database and student factors. The difference is on the curriculum $\left(x^{-}=2.86\right)$, the data base $\left(x^{-}=2.49\right)$ and the student $\left(x^{-}=3.67\right)$ dimensions between academicians from the state and the foundation universities, and this difference is statistically significant.

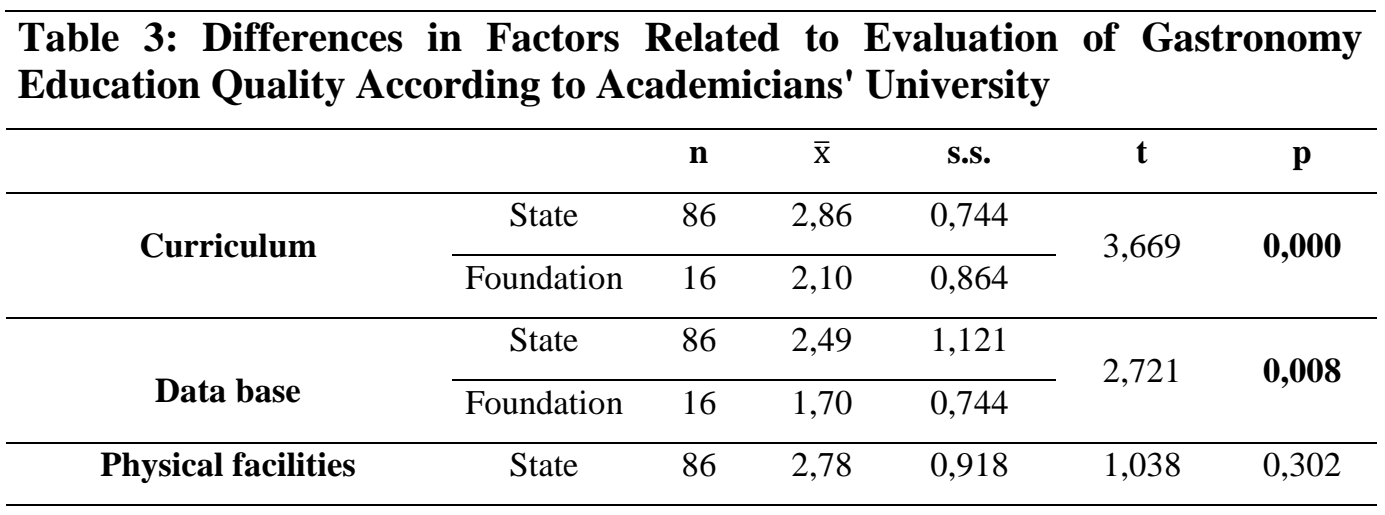




\begin{tabular}{lcccccc}
\hline & Foundation & 16 & 2,52 & 0,938 & & \\
\hline \multirow{2}{*}{ Student } & State & 86 & 3,67 & 0,705 & \multirow{2}{*}{2,982} & \multirow{0}{*}{$\mathbf{0 , 0 0 4}$} \\
\cline { 2 - 5 } & Foundation & 16 & 3,09 & 0,740 & & \\
\hline
\end{tabular}

Independent sample t-tests were applied to determine whether there is a significant difference on curriculum, data base, physical facilities and student factors according to the departments (culinary or gastronomy) of the academicians. As seen in Table 4, no significant difference was found between the factors related to the evaluation of the quality of gastronomy education between the programs of academicians. However, when we look at the general average of all the factors, academicians have less agreement on all factors except student factor.

Table 4: Differences in Factors Related to Evaluation of Gastronomy Education Quality According to Academicians' Departments

\begin{tabular}{|c|c|c|c|c|c|c|}
\hline & & $\mathbf{n}$ & $\overline{\mathrm{x}}$ & S.S. & $\mathbf{t}$ & $\mathbf{p}$ \\
\hline \multirow[b]{2}{*}{ Curriculum } & Culinary & 72 & 2,72 & 0,842 & \multirow[b]{2}{*}{-423} & \multirow[b]{2}{*}{0,673} \\
\hline & $\begin{array}{c}\text { Gastronomy and culinary } \\
\text { departments }\end{array}$ & 30 & 2,80 & 0,733 & & \\
\hline \multirow[b]{2}{*}{ Data base } & Culinary & 72 & 2,29 & 1,131 & \multirow[b]{2}{*}{$-1,077$} & \multirow[b]{2}{*}{0,284} \\
\hline & $\begin{array}{c}\text { Gastronomy and culinary } \\
\text { departments }\end{array}$ & 30 & 2,55 & 1,042 & & \\
\hline \multirow[b]{2}{*}{ Physical facilities } & Culinary & 72 & 2,67 & 0,897 & \multirow[b]{2}{*}{$-1,199$} & \multirow[b]{2}{*}{0,233} \\
\hline & $\begin{array}{c}\text { Gastronomy and culinary } \\
\text { departments }\end{array}$ & 30 & 2,91 & 0,972 & & \\
\hline \multirow[b]{2}{*}{ Student } & Culinary & 72 & 3,61 & 0,753 & \multirow[b]{2}{*}{-647} & \multirow[b]{2}{*}{0,519} \\
\hline & $\begin{array}{c}\text { Gastronomy and culinary } \\
\text { departments }\end{array}$ & 30 & 3,50 & 0,706 & & \\
\hline
\end{tabular}

\section{Findings Related to Students}

\section{Demographic Characteristics of Students}

The demographic characteristics of the students of gastronomy programs are given in Table 5. It is seen that $83,3 \%$ of the students have been studying at the state university and $16,7 \%$ of them are at the foundation university. $85.3 \%$ of the students are in the culinary program and $14.7 \%$ of the students are in the gastronomy and culinary arts.

\section{Table 5: Demographic Characteristics of Students (n: 400)}

\begin{tabular}{clrr}
\hline \multirow{2}{*}{ Universty } & & $\mathbf{n}$ & $\boldsymbol{\%}$ \\
\hline \multirow{2}{*}{ Department } & State & 333 & 83,3 \\
\cline { 2 - 5 } & Foundation & 67 & 16,7 \\
\hline & Gastronomy and culinary departments & 59 & 14,7 \\
\cline { 2 - 5 } & Culinary & 341 & 85,3 \\
\hline
\end{tabular}




\section{Arithmetic Mean and Standard Deviations of Factors Related to Evaluation of Gastronomy Education Quality of Students}

Students are asked to score the items from 1 to 5 according to a 5-point Likert scale to assess the quality of the gastronomy education. The arithmetic mean $\mathrm{x}^{-}$and standard deviation (s.s) values of items related to evaluation of gastronomy education quality are shown in Table 6. Acording to it, the students agreed on the curriculum (2.96), the database (2.95), and the physical facilities factor (2.90), while the teaching agreed on the faculty factor $(3,62)$. When the scores of students' about items one by one and the means of the factors are examined, it is seen that they generally express negative comments for the factors except the faculty factor. It is also seen that of all the items "the number of practical courses is sufficient" $(2,45)$ and "the students can find sufficient financial support" $(2,39)$ have the lowest scores, even below 2,50.

\section{Table 6: Arithmetic Mean and Standard Deviation of Students as to Evaluating Gastronomy Education Quality}

\begin{tabular}{|c|c|c|c|c|}
\hline Factors & Statements & $\overline{\mathrm{x}}$ & S.s. & $\begin{array}{l}\text { Factors } \\
\text { Means }\end{array}$ \\
\hline \multirow{9}{*}{ Curriculum } & $\begin{array}{l}\text { Theoretical courses of the curriculum includes different disciplines } \\
\text { (communication, agriculture, sociology, chemistry, art and accounting) }\end{array}$ & 3,06 & 1,339 & \multirow{9}{*}{2,96} \\
\hline & $\begin{array}{l}\text { The curriculum includes courses which improves creativity and } \\
\text { imagination }\end{array}$ & 3,01 & 1,381 & \\
\hline & Course lecturers are experts of their fields & 3,14 & 1,352 & \\
\hline & Applied courses are of enough variety & 2,55 & 1,400 & \\
\hline & Applied courses are of enough number & 2,45 & 1,390 & \\
\hline & Applied courses are of enough hours & 2,87 & 1,488 & \\
\hline & There are repetitive courses in the curriculum & 3,13 & 1,348 & \\
\hline & $\begin{array}{l}\text { The curriculum is prepared according to needs and expectations of the } \\
\text { industry }\end{array}$ & 3,09 & 1,252 & \\
\hline & Course contents support team working & 3,35 & 1,289 & \\
\hline \multirow{5}{*}{ Data Base } & Webpage of the school presents e-sources for vocational training & 2,86 & 1,311 & \multirow{5}{*}{2,95} \\
\hline & $\begin{array}{l}\text { Webpage of the school includes information for pursuit of vocational } \\
\text { trends }\end{array}$ & 2,85 & 1,319 & \\
\hline & Webpage of the school has links for information outsources & 2,86 & 1,279 & \\
\hline & $\begin{array}{l}\text { Webpage of the school presents information on vocational activities such } \\
\text { as culinary contents, conferences, seminaries and fairs }\end{array}$ & 3,08 & 1,329 & \\
\hline & $\begin{array}{l}\text { Webpage of the school has a user friendly (easy to access and use) } \\
\text { interface }\end{array}$ & 3,13 & 1,300 & \\
\hline \multirow{4}{*}{$\begin{array}{l}\text { Physical } \\
\text { Facilities }\end{array}$} & There enough computers and usage opportunties & 2,81 & 1,441 & \multirow{4}{*}{2,90} \\
\hline & There are enough electronic and printed sources in the library & 2,59 & 1,398 & \\
\hline & There are enough sectoral practice facilities out of the school & 2,66 & 1,357 & \\
\hline & There enough accomodation facilities for the students & 2,69 & 1,394 & \\
\hline
\end{tabular}




\begin{tabular}{|c|c|c|}
\hline There enough funding sources for the students & 2,39 & 1,306 \\
\hline $\begin{array}{l}\text { There are enough technological training equipment (projector, sound } \\
\text { system etc.) in the classrooms }\end{array}$ & 3,09 & 1,401 \\
\hline There are enough practice facilites in the school & 2,99 & 1,425 \\
\hline $\begin{array}{l}\text { There are enough application kitchen equipment for preparing students } \\
\text { for the sector }\end{array}$ & 2,99 & 1,501 \\
\hline The applicaiton kitchen is sanitized and hygenic enough & 3,39 & 1,433 \\
\hline The lecturers-students ratio in applicational courses is appropriate & 2,96 & 1,459 \\
\hline There is no stock provision problems in the application kitchen & 3,10 & 1,517 \\
\hline The campus is secure enough & 3,45 & 1,383 \\
\hline
\end{tabular}

\section{Continued from Table 6}

\begin{tabular}{|c|c|c|c|c|}
\hline Factors & Statements & $\overline{\mathrm{x}}$ & s.s. & $\begin{array}{l}\text { Factors } \\
\text { Means }\end{array}$ \\
\hline \multirow{15}{*}{$\begin{array}{c}\text { Teaching/ } \\
\text { Academician }\end{array}$} & Guides the students with passion & 3,42 & 1,329 & \multirow{15}{*}{3,62} \\
\hline & Ensures the necessary atmosphere for effective learning in the class & 3,51 & 1,276 & \\
\hline & Makes personal contacts with the students and is easily accessible & 3,66 & 1,304 & \\
\hline & Has enough theretical knowledge & 3,65 & 1,266 & \\
\hline & Has enough skills of vocational practice & 3,61 & 1,287 & \\
\hline & Refrains from conventional education techniques & 3,35 & 1,310 & \\
\hline & Supports students for free thinking & 3,63 & 1,289 & \\
\hline & Encourages students to research & 3,62 & 1,276 & \\
\hline & $\begin{array}{l}\text { Encourages students to show their personal imaginations and creativities } \\
\text { in rehearsals }\end{array}$ & 3,79 & 1,264 & \\
\hline & Provides additional information when evaluating the students' plates & 3,71 & 1,274 & \\
\hline & Behaves ethical when evaluating the student & 3,57 & 1,337 & \\
\hline & Uses educational materials effectively & 3,68 & 1,228 & \\
\hline & Is open to innovative thinking and criticism & 3,65 & 1,247 & \\
\hline & Prepares her/his students for the sector & 3,73 & 1,235 & \\
\hline & Has contacts with sector professionals and professional communities & 3,67 & 1,214 & \\
\hline
\end{tabular}

\section{Findings Related to Independent Sample t Test Analysis}

To the data obtained from the questionnaire applied to the students, an independent sample t-test was applied to determine whether there is a meaningful difference in curriculum, data base, physical facilities and faculty factors according to the university. As shown in Table 7, there was a statistically significant difference between the universities of the students on 
curriculum, physical facilities and teaching factors. The mean scores of the students of the foundation university is different from the students of state universities on the curriculum (3.33), physical facilities (3.56) and the faculty (3.95), and this difference is statistically significant.

\section{Table 7: Differences in Factors Related to Evaluation of Gastronomy Education Quality According to Students' University}

\begin{tabular}{|c|c|c|c|c|c|c|}
\hline & & $\mathbf{n}$ & $\overline{\mathrm{x}}$ & S.S. & $\mathbf{t}$ & $\mathbf{p}$ \\
\hline \multirow{2}{*}{ Curriculum } & State & 333 & 2,89 & 0,810 & \multirow{2}{*}{$-3,874$} & \multirow{2}{*}{$\mathbf{0 , 0 0 0}$} \\
\hline & Foundation & 67 & 3,33 & 1,017 & & \\
\hline \multirow{2}{*}{ Data Base } & State & 333 & 2,92 & 1,067 & \multirow{2}{*}{$-1,292$} & \multirow{2}{*}{0,197} \\
\hline & Foundation & 67 & 3,11 & 1,252 & & \\
\hline \multirow{2}{*}{ Physical Facilities } & State & 333 & 2,77 & 0,935 & \multirow{2}{*}{$-6,287$} & \multirow{2}{*}{0,000} \\
\hline & Foundation & 67 & 3,56 & 0,953 & & \\
\hline \multirow{2}{*}{ Teaching/Academician } & State & 333 & 3,55 & 1,009 & \multirow{2}{*}{$-2,846$} & \multirow{2}{*}{0,005} \\
\hline & Foundation & 67 & 3,95 & 1,174 & & \\
\hline
\end{tabular}

Independent sample t-tests were applied to determine whether there is a significant difference on curriculum, data base, physical facilities and faculty factors according to their departments (culinary-gastronomy). As shown in Table 8, there is a statistically significant difference between the students merely on the physical factors. The factor mean of physical facilities $(3,46)$ of students from gastronomy and culinary arts programs are different from the students from culinary, and this difference is statistically significant.

Table 8: Differences in Factors Related to Evaluation of Gastronomy Education Quality According to Students' Departments

\begin{tabular}{|c|c|c|c|c|c|c|}
\hline & & $\mathbf{n}$ & $\overline{\mathrm{x}}$ & S.S. & $\mathbf{t}$ & $\mathbf{p}$ \\
\hline \multirow[b]{2}{*}{ Curriculum } & Culinary & 341 & 2,96 & 0,882 & \multirow[b]{2}{*}{-083} & \multirow[b]{2}{*}{0,934} \\
\hline & $\begin{array}{c}\text { Gastronomy and culinary } \\
\text { departments }\end{array}$ & 59 & 2,95 & 0,746 & & \\
\hline \multirow[b]{2}{*}{ Data Base } & Culinary & 341 & 2,97 & 1,116 & \multirow[b]{2}{*}{,758 } & \multirow[b]{2}{*}{0,449} \\
\hline & $\begin{array}{l}\text { Gastronomy and culinary } \\
\text { departments }\end{array}$ & 59 & 2,85 & 1,007 & & \\
\hline \multirow[b]{2}{*}{ Physical Facilities } & Culinary & 341 & 2,81 & 0,981 & \multirow[b]{2}{*}{$-4,820$} & \multirow[b]{2}{*}{$\mathbf{0 , 0 0 0}$} \\
\hline & $\begin{array}{l}\text { Gastronomy and culinary } \\
\text { departments }\end{array}$ & 59 & 3,46 & 0,791 & & \\
\hline \multirow[b]{2}{*}{ Teaching/Academician } & Culinary & 341 & 3,63 & 1,068 & \multirow[b]{2}{*}{-549} & \multirow[b]{2}{*}{0,583} \\
\hline & $\begin{array}{c}\text { Gastronomy and culinary } \\
\text { departments }\end{array}$ & 59 & 3,55 & 0,928 & & \\
\hline
\end{tabular}


An independent sample t-test was applied to determine whether there is a significant difference between academicians and students on curriculum, data base, and physical possibilities. As seen in Table 9, a significant difference was found in data base and curriculum factor between academicians and student. It is also seen that the students have higher agreement rate than the academicians. However, factor means indicates that both academicians and students are not satisfied with the curriculum, the database and the physical possibilities of the gastronomy education of the universities.

Table 9: Differences in Factors Related to Evaluation of Gastronomy Education Quality by Title

\begin{tabular}{ccccccc}
\hline & & $\mathbf{n}$ & $\overline{\mathbf{x}}$ & $\mathbf{s . s .}$ & $\mathbf{t}$ & $\mathbf{p}$ \\
\hline \multirow{2}{*}{ Curriculum } & Student & 400 & 2,96 & 0,863 & \multirow{2}{*}{2,305} & \multirow{2}{*}{$\mathbf{0 , 0 2 2}$} \\
\cline { 2 - 5 } Data Base & Teaching/Academician & 102 & 2,74 & 0,809 & & \\
\cline { 2 - 5 } & Student & 400 & 2,95 & 1,101 & \multirow{2}{*}{4,804} & \multirow{2}{*}{$\mathbf{0 , 0 0 0}$} \\
\cline { 2 - 5 } Physical Facilities & Teaching/Academician & 102 & 2,37 & 1,107 & & \\
\cline { 2 - 5 } & Student & 400 & 2,90 & 0,982 & \multirow{2}{*}{1,512} & \multirow{2}{*}{0,131} \\
\cline { 2 - 5 } & Teaching/Academician & 102 & 2,74 & 0,922 & & \\
\hline
\end{tabular}

\section{CONCLUSIONS AND SUGGESTIONS}

From the studies on gastronomy education and its quality, five dimensions of gastronomy education can be conluded. These are; curriculum, physical facilities, database, faculty and student (Hertzman and Ackerman, 2010; Naidu and Derani, 2016; Ko, 2012; Wollin and Gravas, 2013; Ko and Chiu, 2011; Kuo, Burnard, McLellan, Cheng, and Wu, 2017; ESG, 2018; ACF, 2018; Ontario, 2018; GACHEF, 2018; WACS, 2018). It's seen that in order to reach the quality in gastronomy education can be possible with; the faculty graduate from relative fields, capable of professional skills, can think analytic and critical; the cirriculum which provides students to take part in all learning process, is open the flexible learning, shaped by all stakeholders' (university, student, sector) perceptions, convenient with internetional acreditations; the phisical facilities which has enough and accesible equipment in quantity and quality; and, the database which give linkages to useful, helpful and relevant sources and professional institutions. By this line of research, the quality of higher gastronomy education in Turkey was handled and evaluated under the dimentions of curriculum, physical facilities, databases, student and faculty. And, the results of the research show that the curriculum, physical facilities and databases are not adequate for the sake of gastronomy education quality.

Gastronomy, culinary, and foodandbeverage management programs are quite popular among the students lately. However, the inadequacies in these educational dimensions mentioned before, cause serious negativities and poor performance in the quality of the institutions and hence the education institutions can't fulfil their responsibilities for educating and graduating qualified and sector-ready labor.

For the future of these new and rapidly developing programs, inadequacies and its reasons has to be discussed seriously and bravely by gastronomy related academic staff. Therefore, the strategic goals of these programs need to be set by competent academicians who have graduated from related fields. 


\section{REFERENCES}

Abdullah, F. (2006). The development of HEdPERF: a new measuring instrument of service quality for the higher education sector. International Journal of Consumer Studies, 6(30), 569-581 . doi:10.1111/j.1470-6431.2005.00480.x

ACF. (2018, Temmuz 20). American Culinary Federation: https://www.acfchefs.org/ACF/Education/Accreditation/ACF/Education/Accreditation/

Brown, J. N. (2013). A Brief History of Culinary Arts Education in America. Journal of Hospitality and\#x26; Tourism Education. doi:DOI: 10.1080/10963758.2005.10696841

Brown, J. N. (2014). Integrating Eisner's Arts Education Philosophy into Culinary Arts Education. Journal of Culinary Science and Technology, 4(1), s. 89-99. doi:DOI: 10.1300/J385v04n01_10

Brown, J. N., Mao, Z. “., and Chesser, J. W. (2013). A Comparison of Learning Outcomes in Culinary Education: Recorded Video vs. Live Demonstration. Journal of Hospitality and\#x26; Tourism Education 25:3, s. 103-109. doi:DOI: 10.1080/10963758.2013.826940

ESG. (2015). Standards and Guidelines for Quality Assurance in the European Higher Education Area. http://www.enqa.eu: http://www.enqa.eu/wpcontent/uploads/2015/11/ESG_2015.pdf

GACHEF. (2018, Temmuz 20). The Culinary Arts Industry Accreditation. www.gadoe.org: https://www.gadoe.org/Curriculum-Instruction-and-

Assessment/CTAE/Documents/GACHEF-Culinary-Arts-Industry-AccreditationManual.pdf

Görkem, O., and Sevim, B. (2016). Gastronomi Eğitiminde Geç mi Kalınd1, Acele mi Ediliyor? Elektronik Sosyal Bilimler Dergisi, 15(58), 977-988. doi:10.17755/esosder.06573

Gustafsson, I.-B., Öström, Å., and Annett, J. (2009). Culinary Arts And Meal Science As An İnterdisciplinary University Curriculum. Culinary arts and meal science, s. 270-293.

Hegarty, J. A. (2011). Achieving Excellence by Means of Critical Reflection and Cultural Imagination in Culinary Arts and Gastronomy Education. Journal of Culinary Science and Technology, s. 55-65. doi:10.1080/15428052.2011.580705

Hertzman, J., and Ackerman, R. (2010). Evaluating quality in associate degree culinary arts programs. Quality Assurance in Education, 18(3), s. 209-226. doi:DOI 10.1108/09684881011058650

Ko, W.-H. (2012). A Study of the Relationships Among Effective Learning, Professional Competence, and Learning Performance in Culinary Field. JournalofHospitality, Leisure,SportandTourismEducation 11, s. 12-20. doi:doi:10.1016/j.jhlste.2012.02.010

Ko, W.-H., and Chiu, Y.-H. (2011). Developing Teaching Quality Indicators For The Culinary Teacher in A University. World Transactions on Engineering and Technology Education, 9(2).

Kozak, N., and Açıköz, Z. (2015). 7. Akademik Turizm Eğitimi Arama Konferansı Sonuç Raporu. T. A. Anatolia: Turizm Araştırmaları Dergisi (Dü.). içinde İstanbul: Nazmi Kozak. 
Kuo, H.-C., Burnard, P., McLellan, R., Cheng, Y.-Y., and Wu, J.-J. (2017). The Development of Indicators for Creativity Education and a Questionnaire to Evaluate its Delivery and Practice. Thinking Skills and Creativity. doi:http://dx.doi.org/doi:10.1016/j.tsc.2017.02.005

Kurnaz, A., Kurnaz, H. A., and Kılıç, B. (2014). Önlisans Düzeyinde Eğitim Alan Aşçılık Programı Öğrencilerinin Mesleki Tutumlarının Belirlenmesi . Muğla Sıtkı Koçman Üniversitesi Sosyal Bilimler Enstitüsü Dergisi(32), 41-61.

Müller, K. F., and Harrington, R. J. (2009). The Effectiveness Of Culinary Curricula: A Case Study. International Journal of Contemporary Hospitality Management, 21(2), s. 167178. doi:DOI 10.1108/09596110910935660

Naidu, P., and Derani, N. E. (2016). A Comparative Study on Quality of Education Received by Students of Private Universities versus Public Universities. Procedia Economics and Finance 35, s. 659 - 666. doi:10.1016/S2212-5671(16)00081-2

Ontario. (2018, Temmuz 20). Ministry of Training, Colleges and Universities: http://www.tcu.gov.on.ca/pepg/audiences/colleges/progstan/hosptour/culinary_skills_431 07_e_20160831.pdf

Öney, H. (2016). Gastronomi Eğitimi Üzerine Bir Değerlendirme. Selçuk Ün. Sos. Bil. Ens. Der., s. 193-203.

Santich, B. (2004). The Study Of Gastronomy And Its Relevance To Hospitality Education And Training. Hospitality Management 23, s. 15-24. doi:doi:10.1016/S0278-4319(03)00069-0

Shani, A., Belhassen, Y., and Soskolne, D. (2013). Teaching Professional Ethics in Culinary Studies. Journal of Contemporary Hospitality Management, 25(3), s. 447 - 464. doi:DOI 10.1108/09596111311311062

Temizkan, R., Cankül, D., and Kızıltaş, Ç. (2018). Food And Beverage Education and Scholars' in Turkey. Journal of Gastronomy, Hospitality, and Travel, 1(2), 18 - 25.

WACS. (2018, Temmuz 20). Twelve Standards of Quality Culinary Education. www.worldchefs.org: https://www.worldchefs.org/Education/School/Twelve-StandardsOf-Quality-Culinary-Education

Way, K. A., Ottenbacher, M. C., and Harrington, R. J. (2011). Is Crowdsourcing Useful for Enhancing Innovation and Learning Outcomes in Culinary and Hospitality Education? Journal of Culinary Science and Technology, s. 261-281. doi:DOI: 10.1080/15428052.2011.627259

Wollin, M., and Gravas, S. (2013). A Proposed Curriculum and Articulation Model for Two-Year Degree Programs in Culinary Arts. Journal of Hospitality and Tourism Education, s. 2339. doi:10.1080/10963758.2001.10696688

YÖK. (2017). YÖK ATLAS: http://www.yok.gov.tr/web/guest/universitelerimiz

YÖK (2017). YÖK ATLAS https://yokatlas.yok.gov.tr/tercih-sihirbazi-t4-tablo.php?p=ts2

Zahari, M. S., Jalis, M. H., Zulfifly, M. I., Radzi, S. M., and Othman, Z. (2009). Gastronomy: An Opportunity for Malaysian Culinary Educators. International Education Studies, 2(2). 
Zopiatis, A., Theodosiou, P., and Constanti, P. (2014). Quality and Satisfaction With Culinary Education: Evidence From Cyprus. Journal of Hospitality and Tourism Education, 26(2), s. 87-9. doi:DOI:10.1080/10963758.2014.900383 